\title{
ПСИХОЛОГІЧНІ ОСОБЛИВОСТІ ДІТЕЙ МОЛОДШОГО ШКІЛЬНОГО ВІКУ ІЗ СИНДРОМОМ ГІПЕРАКТИВНОСТІ
}

\section{Атаманчук Ніна Михайлівна}

Кандидат психологічних наук, дочент кафедри загальної, вікової та практичної психології Полтавського національного педагогічного університету імені В. Г. Короленка, м. Полтава (Україна)

Анотація. Стаття пов'язана з теоретичним аналізом та емпіричним дослідженням психологічних особливостей гіперактивних молодших школярів.

Виявлено, що учнів із синдромом гіперактивності найбільше характеризує рухова розгальмованість. Великий відсоток поміж досліджуваних дітей мають порушення, які стосуються дефіциту активної уваги та проявів імпульсивності.

Схарактеризовані основні психологічні особливості гіперактивних дітей; встановлено, що в гіперактивних школярів досить часті прояви знервованості, агресії, нетерплячості, різкої зміни настрою, чутливість до критики або ігнорування зауважень дорослих та ін.

Зроблено висновок, що гіперактивні діти не мали затримки інтелектуального розвитку, але проблеми в навчанні виникали переважно через непосидючість, невміння концентрувати увагу. Маючи достатній потенціал для засвоєння навчальної програми, ці діти небажані в школі, однокласники їх не сприймають. Гіперактивні діти досить часто виявляють жорстокість до своїх ровесників, вони - винуватиі конфліктів, щзо спричиняе напружені ситуації.

Укладено пам'ятки для батьків, педагогів гіперактивних учнів. Подано тест «Знайди відмінності». Шкільним психологам для роботи з гіперактивними дітьми молодтого шкільного віку запропоновано комплекс занять, спрямованих на зниження тривожності, страхів, підвищення зосередження, самооцінки та отримання насолоди від мистецтва.

Ключові слова: гіперактивність, дефіцит активної уваги, імпульсивність, рухова розгальмованість, зовнішні прояви гіперактивності.

Постановка проблеми. У сучасному стрімкому світі все частіше й частіше зустрічаються гіперактивні діти. Це малята, які постійно активно рухаються. Вони не можуть си- діти на місці ні хвилини, стрибають, бігають, багато говорять, потребують безперервного руху не тільки на фізичному, але й психологічному рівні. Гіперактивність вважають не 
рисою характеру дитини, а нервовим порушенням. Проте не всім гіперактивним дітям необхідне спеціальне медикаментозне лікування. Для того, щоб полегшити стан дитини, бажано створити спокійні умови життя. Тільки спілкуючись зі спокійними людьми, дитина навчиться контролювати себе.

Проблема ефективності освіти гіперактивних дітей набуває все більшої актуальності і все частіше стає предметом обговорення поміж учителів та шкільних психологів. Сучасна школа не адаптована до роботи 3 надмірно активними й імпульсивними дітьми. Вони не відповідають нормативним рамкам. Навчальний процес, у тому вигляді, у якому він існує, не ефективний для гіперактивної дитини.

У школі провідний вид діяльності навчальна діяльність, що збільшує інтелектуальні навантаження, а саме: уміння триваліше концентрувати увагу, доводити розпочату справу до кінця, досягати певного результату. Учителі та батьки раптом виявляють непосидючість, неорганізованість, надмірну рухливість учня.

У зв'язку з великою поширеністю гіперактивності в шкільному віці, особливо в початковій школі та широкою різноманітністю супроводжувальних симптомів збільшується вірогідність помилкового діагнозу, і як наслідок - некоректної терапії. Часто вчителі не можуть без допомоги досвідченого фахівця відрізнити гіперактивність від інших психо- логічних особливостей поведінки проблемного школяра. У результаті застосовують різні виховні заходи, у тому числі покарання, які часто не лише даремні, але й провокативні для такої дитини.

Слід визнати: в Україні рівень обізнаності щодо гіперактивності дітей і в суспільстві, і поміж фахівців залишається низьким. Мало вивчена і соціальна значущість цієї проблеми. На жаль, переважна частина гіперактивних дітей не отримує належної допомоги. Це зумовлює необхідність вивчення, систематизації та узагальнення психологічних особливостей гіперактивних дітей.

Аналіз досліджень і публікацій. Проблема діагностики та корекції гіперактивності досить широко досліджена й висвітлена в науковій літературі країн Свропи, США, але недостатньо - в Україні. Питання гіперактивності вивчали Л. Алексєєва, І. Брязгунов, О. Гуріна, О. Касатікова, О. Кричтон, М. Заваденко, В. Зінченко, Н. Іовчук, А. Комелева, Б. Мещеряков, О. Лютова, О. Романчук, А. Сиротюк, Ю. Шевченко та інші.

3 середини XIX століття гіперактивний розлад трактували лише 3 медичного погляду, психологічний рівень такого розладу не враховували. Так, у 1845 році німецький невропатолог Г. Хофман відтворив у книзі для дитячого читання випадок імпульсивної поведінки дитини на ім'я Фіджеті Філ 
(непосидючий, неспокійний). Хлопчик ні секунди не міг спокійно сидіти на стільці [5].

На початку XX століття педіатр Дж. Стіл у своїй лекції описав 43 випадки порушення уваги, гіперактивності, імпульсивної та гіперактивної поведінки в дітей. Він припустив, що така поведінка - результат спадкової патології або пологових травм [5].

У 60-х роках XX століття лікарі вважали гіперактивність патологією і пояснювали їі мінімальними розладами функцій мозку. У 80 -х роках надмірну рухову активність стали відносити до самостійних захворювань, назвавши «синдром дефіциту (порушення) уваги 3 гіперактивністю» (СДУГ).

К. Хеллером (1904р.) описав дітей із проявами рухового неспокою, імпульсивністю, порушеннями уваги [8].

$\Phi$. Крамер (F. Kramer) та Х. Паллнов (H. Pollnow) (1932 р.) розширили перелік причин гіперактивного синдрому. Вони спиралися в основному на анатомічні дані дослідження та дійшли висновку про органічну церебральну недостатність у таких дітей [9].

Шотландський лікар О. Кричтон уперше зробив спробу описати симптоми дитячої гіперактивності з психологічного погляду. Вивчаючи зазначену проблему, О. Кричтон характеризував гіперактивність як вроджену хронічну незграбність, що обов'язково призводить до розладів соціальної адаптації [10].

Гіперактивність (лат. «активний» - діяльний, а грецьке «гіпер» - перевищення нор- ми) - надмірна фізична й розумова активність у дітей. Найяскравіші іiі прояви бачимо в старших дошкільнят і молодших школярів. Така дитина - нетерпляча та метушлива, імпульсивна та агресивна. Вона не може утримувати на чомусь увагу більше, ніж 5-10 хвилин. Багато й швидко розмовляє, ставить безліч запитань, але відповідей не чекає, бо встигає зацікавитися іншим [6, с. 8-9].

Отже, сказане вище дає підстави стверджувати: гіперактивність - це сукупність симптомів, пов'язаних із надмірною психічною та моторною активністю.

За С. Головним, дитяча гіперактивність (hyperactivity) - відхилення від вікових норм онтогенетичного розвитку, що характеризується неуважністю, відволіканням, імпульсною поведінкою в інтелектуальній та соціальній діяльності, підвищеною руховою активністю при нормальному рівні інтелектуального розвитку [2].

Науковці В. Зінченко і Б. Мещеряков до зовнішніх проявів гіперактивності відносять неуважність, імпульсивність, підвищену рухову активність [6, с. 12].

Л. Чутко характеризує гіперактивних дітей як непосидючих, неуважних, імпульсивних та наголошує на тому, що синдром гіперактивності заважає їхній соціальній адаптації $[7]$.

Дослідники Ю. Шевченко, Н. Заваденко виділяють три основні форми вияву гіперактивності: 
1) дефіцит уваги;

2) імпульсивність;

3) підвищена рухова активність.

Р. Кемпбелл до проявів гіперактивності зараховує розлад сприймання. Він уважає, що підвищена активність спричиняє труднощі в навчанні.

Американські психологи П. Бейкер i М. Алворд пропонують такі критерії виявлення гіперактивності в дитини:

1. Дефіцит активної уваги (непослідовна, їй важко довго утримувати увагу; не слухає, коли до неї звертаються; $з$ великим ентузіазмом береться за завдання, але так і не завершує його; відчуває труднощі в організації; уникає нудних і тих, що вимагають розумових зусиль, завдань);

2. Рухове розгальмування (постійно рухається; виявляє ознаки занепокоєння; спить набагато менше, ніж інші діти, навіть у дитинстві);

3. Імпульсивність (починає відповідати, не дослухавши питання; часто втручається; перериває; не може дочекатися винагороди; при виконанні завдань поводиться по-різному й показує дуже різні результати).

Великий інтерес викликають праці Ю. Олександровського про шкільну дезадаптацію дітей із синдромом гіперактивності. Дослідник характеризує гіперактивних дітей як невпевнених, із заниженою самооцінкою, фобіями, опозиційною та агресивною поведінкою [1].
Таким чином, психологи виділяють такі ознаки гіперактивності в дітей: надмірна рухова активність, імпульсивність, відволікання-неуважність.

На сьогодні $з$ погляду педагогічного підходу до вивчення синдрому гіперактивності здійснено значно менше досліджень, ніж із медичного та психологічного. Цю проблему вивчали: Т. Борисова, Т. Смельянцева, О. Куцінко, Л. Матюхіна, Л. Прокопів, А. Чумакова, О. Ферт, Л. Ясюкова та інші.

Науковці досліджують ступінь та структуру розповсюдженості синдрому гіперактивності поміж першокласників 3 метою, головно, психопрофілактики.

Результати досліджень Л. Матюхіна, Т. Борисова, Т. Смельянцева вказують на високу поширеність синдрому гіперактивності в дітей першого року навчання - кожен п'ятий першокласник має високий ризик розвитку такого розладу поведінки.

Учителі початкових класів, які працюють із гіперактивними учнями, наголошують на тому, що з такими школярами нелегко контактувати. Проблеми в навчанні в них виникають переважно через непосидючість, невміння концентрувати увагу. На перерві гіперактивна дитина - ініціатор безглуздої біганини, штовханини, частих конфліктних ситуацій із однокласниками, що ведуть до непорузоміння та неприйняття їх ровесниками.

Цілеспрямована допомога дітям із синдромом гіперактивності та їхнім батькам роз- 
почалася в Україні з XXI століття. I. Марценковський, Я. Бікшаєва, О. Ткачова (2006р.) публікують праці в українських медичних виданнях $з$ проблеми синдрому гіперактивності.

Аналіз вітчизняної та зарубіжної літератури засвідчує, що поведінка гіперактивних дітей - об'єкт дослідження різних фахівців; найбільше робіт - це дослідження медичного спрямування.

Мета дослідження - проаналізувати i систематизувати психологічні особливості гіперактивних учнів та визначення їхнього впливу на поведінкові вияви дітей.

Виклад основного матеріалу. Нами було проведено дослідження у 2016-2017 рр. на базі Полтавських загальноосвітніх шкіл IIII ступенів. У ньому брали участь 120 учнів початкових класів.

Емпіричне дослідження проводили у два етапи. Для діагностики гіперактивного розладу в дітей важливе спостереження за їхньою поведінкою та виявлення таких ознак, як рухливість, труднощі зосередження та довільної регуляції дій, імпульсивність. Така інформація добре відома дорослим, які багато часу проводять із дитиною: батькам, педагогам. Цю особливість ми врахували при підборі методів вивчення гіперактивних школярів. Нами застосовувався теоретичний аналіз, емпіричні методи, а саме: метод природного експерименту, під час якого вдалися до методу включеного спостереження, бесіди, схема спостережень за дитиною «Критерії визначення гіпе- рактивності» (за П. Бейкером і М. Алвордом), проективна методика «Кактус» (за М. Панфіловою). За дітьми спостерігали протягом тривалого часу. Адже короткочасне спостереження за виявами їхньої емоційної та поведінкової сфери не дозволить впевненено говорити про синдром гіперактивності.

\section{Перший eman дослідження був} спрямований на визначення гіперактивності в дітей та з'ясування типів порушень у них. Ми застосували схему спостережень за дитиною «Критерії визначення гіперактивності» (за П. Бейкером і М. Алвордом).

Під час дослідження використовували кілька критеріїв діагностики синдрому гіперактивності. Дитині молодшого шкільного віку без інтелектуальних порушень може бути поставлений діагноз «синдром гіперактивності» за умови наявності 6 або більше ознак порушення поведінки. Симптоми мають проявлятися протягом майже шести місяців у двох сферах діяльності (вдома і в школі).

На основі аналізу даних, отриманих у результаті використання схеми спостережень за дитиною, нами було виділено 16,6 \% гіперактивних дітей від загальної кількості досліджуваних.

Нами встановлено, що в гіперактивних школярів досить часті прояви знервованості, агресії, нетерплячості, різкої зміни настрою, чутливість до критики або ігнорування зауважень дорослих та ін.

Маючи достатній потенціал для засво- 
єння навчальної програми, ці діти небажані в школі, однокласники їх не сприймають. Гіперактивні діти досить часто жорстокі у стосунках зі своїми ровесниками, $€$ винуватцями конфліктів.

Нами підтверджено, що гіперактивні діти 3 достатнім інтелектуальним розвитком зазнають невдач у виконанні завдання з того чи того шкільного предмета насамперед через неспроможність уважно вислухати завдання учителя та виконати всі його вказівки. Такі учні одразу беруться до їх виконання, не осмислюючи доцільності й послідовності виконуваних дій.

Отже, в них випадає процес планування як прояв недостатньої саморегуляції. Зіткнувшись із труднощами, такі діти не намагаються їх подолати, а переключаються на інші види діяльності, які привернули їхню увагу. Вважаємо, що вчителі та батьки мають стимулювати в гіперактивних учнів під час виконання завдань на уроках та вдома зосередженість, концентрацію уваги.

Нами визначено типи порушень, які тивної уваги - 28\%; рухова розгальмованість $47 \%$; імпульсивність - 25\% (табл. 1 ). наявні в гіперактивних школярів: дефіцит ак-

Так, учні з дефіцитом активної уваги важко утримують увагу; не слухають, коли до них звертаються; із великим бажанням беруться за виконання завдань, але так і не закінчують його, відволікаючись на сторонні подразники; зазнають труднощів у самоорганізації; не зібрані, забудькуваті, часто гублять речі; уникають виконання завдань, які потребують розумових зусиль; важко концентрують увагу при виконанні завдань.

Учні з руховою розгальмованістю постійно крутяться; виявляють ознаки занепокоєння (не можуть спокійно сидіти на одному місці); сплять набагато менше, ніж ровесники; полюбляють багато говорити; занадто рухливі; штовхають інших дітей; неспокійні; не можуть тихо, зосереджено займатися чим-небудь у вільний час.

Учні імпульсивні відповідають, не дослухавши питання до кінця; на уроках не здатні чекати своєї черги, постійно перебивають однокласників; часто щось роблять не подумавши; погано зосереджують увагу; безвільні; зі слабо керованою поведінкою; при виконанні завдань поводяться по-різному і показують неоднаковий результат; не думають про наслідки своїх вчинків.

Таблицяя 1.

Типи порушень дітей молодшого шкільного віку із синдромом гіперактивності у \%

\begin{tabular}{|c|c|c|}
\hline \multicolumn{3}{|c|}{ Ознаки порушення поведінки } \\
\hline Дефіцит активної уваги & Рухова розгальмованість & Імпульсивність \\
\hline 28 & 47 & 25 \\
\hline
\end{tabular}

Psychological Journal: Scientific Review of H. S. Kostyuk Institute of Psychology, National Academy of Educational Sciences of Ukraine

(C) Атаманчук H. М. 
Таким чином, характерні риси поведінки гіперактивних дітей - непосидючість, неуважність, негативізм, часта зміна настрою, упертість, запальність, агресивність.

Отже, нами виявлено, що найбільше учнів із синдромом гіперактивності характеризуються руховою розгальмованістю. Великий відсоток поміж досліджуваних дітей мають порушення, що стосуються дефіциту активної уваги та проявів імпульсивності.

Під час другого етапy дослідження проводили індивідуальне діагностичне обстеження кожної гіперактивної дитини, у ході якого виявляли іiі психоемоційні особливості. Враховуючи те, що для дітей із синдромом гіперактивності характерні зміни настрою, переживання, страхи, тривожність, негативізм тощо, а їхні емоції характеризуються бідністю, провели проективну методику М. Панфілової «Кактус» [3; 4], а також використали метод спостереження, розповідей учителів, батьків.

Для виявлення синдрому гіперактивності (проективна методика М. Панфілової «Кактус»), ми акцентували увагу на таких шкалах: агресивність, тривожність, страхи, рухливість, імпульсивність, демонстративність. Дітям було запропоновано намалювати кактус - таким, яким вони його уявляють.

При обробці результатів проективної методики «Кактус» брали до уваги дані, які важливі власне для діагностування синдрому гіперактивності в дітей, а саме: характеристи- ки ліній, сила натиску на олівець, додаткові деталі, кольорова гама тощо. Також враховували специфічні показники, прикметні для цієї методики: характеристика манери малювання (промальований, схематичний тощо), характеристика голок (розмір, розташування, кількість тощо).

За результатами даних, отриманих після аналізу малюнків, нами діагностовано емоційно-особистісні якості молодших школярів із синдромом гіперактивності (табл. 2).

Проаналізувавши малюнки, отримані в ході проведення проективної методики «Кактус», виявили зображення великої кількості голок у 15\% гіперактивних дітей, що вказує на їхню агресивність. У 7\% досліджуваних малюнки 3 темними кольорами: чорний та сірий, що вказує на підвищений рівень тривожності, 42\% гіперактивних учнів малювали жовтим, червоним, зеленим кольорами, що можна пояснити як розкутість, рухливість, активність. У 26\% гіперактивних дітей на малюнку спостерели уривчасті лінії та сильне штрихування, що є ознаками імпульсивності - провідного симптому синдрому гіперактивності. $10 \%$ досліджуваних дітей на малюнках зобразили відростки в кактуса: це засвідчує ознаки демонстративності.

Наведемо приклади розповідей про гіперактивну дитину вчителя та батьків.

Розповідь учителя про досліджувану Марійку 3. (7p. 4м.).

Дисциплінованість дитини залежить 
від часу проведення уроку. На першому уроці дівчинка спокійна, зосереджено виконує завдання. До кінця навчального дня Марійка стає неуважною, неслухняною, дратівливою, слабо підкоряється словесним вказівкам. У зошитах не дописані завдання. Дівчинці важко організувати себе, тому на заняттях потребує додаткової уваги. Маша багато розмовляє, не вислуховує завдання, швидко намагається вгадти відповідь. чи достатнім потенціалом для засвоєння шкільної програми, гіперактивні учні навчаються недостатньо успішно. Вони безглуздо бігають, штовхають інших, провокують конфліктні ситуації. Нерідко в запалі бійки гіперактивні школярі несвідомо жорстокі, їх важко зупинити. Вчителі скаржаться на часте нерозуміння їхнього психічного стану. Вони мають через таких учнів чимало проблем, не можуть знайти вихід із напруженої ситуації.

Таблиця 2

\section{Показники прояву психоемоційних особливостей гіперактивності в дітей молодшо-} го шкільного віку за методикою «Кактус» у \%

\begin{tabular}{|l|l|l|}
\hline \multicolumn{1}{|c|}{ Показники } & \multicolumn{2}{|c|}{ Ознаки прояву гіперактивності } \\
\cline { 2 - 3 } & \multicolumn{2}{|c|}{} \\
\hline Велика кількість голок на малюнку & 15 & Агресивність \\
\hline Перевага чорного, сірого кольорів & 7 & Тривожність, страхи \\
\hline $\begin{array}{l}\text { Перевага жовтого, червоного, зелено- } \\
\text { го кольорів }\end{array}$ & 42 & Рухливість \\
\hline Сильна штриховка, уривчасті лінії & 26 & Імпульсивність \\
\hline Відростки в кактуса & 10 & Демонстративність \\
\hline
\end{tabular}

Учителі початкових класів, які працюють 3 гіперактивними учнями, зазначали про те що, досить важко налагодити контакт і досягти взаєморозуміння із такими школярами, реагувати на спалах неслухняності, імпульсивності, злості, часті непорозуміння із однолітками, непосидючість, надмірну рухливість, активність (не можуть всидіти і п'яти хвилин на одному місці). Працівникам навчальних закладів некомфортно з вихованцями, які заважають іншим дітям засвоювати матеріал на уроках, мають неадекватну поведінку.

Педагоги наголошували, що, володію-
Звісно, все це в часто провокує негативне ставлення учителів до гіперактивних учнів.

Розповідь батьків про досліджувану Марійку 3. (7p., 4м.).

При виконанні домашніх завдань постійно відволікається. До вечора поступово зростає іiі рухлива активність. Засинає з великими труднощами, особливо при порушеннях режиму дня. Надмірно ініціативна, але не може доводити розпочату справу до кінця.

Під час бесід із батьками гіперактивних дітей нами встановлено, що багатьох із них 
незвична поведінка дітей почала турбувати, коли настав час підготовки до школи. Батьків хвилювало те, що їхні малята через свою рухливість не витримають час, відведений на урок, що вони не готові до взаємодії і спілкування із учителями та однолітками. На думку рідних, у їхніх гіперактивних спадкоємців проблеми із соціальною адаптацією пов'язані 3 тим, що батьки інших дітей намагалися тримати своїх малят якомога далі від їхніх дітей. У гіперактивних малят було мало можливостей отримати досвід спілкування та налагодження контактів із ровесниками.

Отже, формування вищезазначених стосунків складні, бо потребують пошуків індивідуальних підходів до дітей, але часто дорослі цього не розуміють, тому намагаються лише заспокоїти малят, змусити їх поводитися, як усі, але ці дії лише ускладнюють соціальну адаптацію гіперактивних учнів.

Таким чином, на підставі отриманих емпіричних результатів ми припускаємо, що 16,6 \% досліджуваних дітей молодшого шкільного віку є гіперактивними, оскільки в них спостерігаються досить часті прояви агресивності, тривожності, страхів, демонстративності поведінки, а найголовніше - імпульсивності та рухової активності.

У ході проведеного дослідження нами виявлено психологічні особливості дітей молодшого шкільного віку із синдромом гіперактивності, а саме:

- непослідовні у виконані завдань;
- уникають виконання завдань, що вимагають постійної уваги;

- часто відволікаються на сторонні подразники;

- схильні до різкої зміни настрою;

- неуважні;

- не доводять розпочату справу до кін-

ця;

- швидко втомЛюються;

- виявляють труднощі в самоорганіза-

ції;

- не зібрані;

- метушливі;

- часто гублять речі;

- забувають виконувати домашні завдання;

- нетерплячі;

- не можуть всидіти на місці;

- викрикують;

- балакучі;

- виявляють надмірну рухову активність під час перерв та уроків;

- агресивні;

- провокують конфліктні ситуації;

- важко знаходять спільну мову з однокласниками;

- задають багато питань;

- відповідають, не дослухавши питан-

ня;

- не чекають своєї черги;

- чутливі до критики;

- мають занижену самооцінку;

- переривають співбесідника; 
- ігнорують зауваження дорослих;

- не здатні контролювати і регулювати свої дії;

- недостатньо контролюють рухи та емоції;

- поведінка слабо керована;

- поведінка непередбачувана, легко переходить від сміху до сліз;

- імпульсивні.

Батькам таких дітей запропонували консультацію спеціалістів. Ми також уклали рекомендації щодо виховання та навчання гіперактивних малят для вчителів та близьких рідних.

Нижче наведемо пам'ятки для учителів i батьків дітей молодшого шкільного віку із синдромом гіперактивності.

Пам'ятка для вчителів.

1. Не вимагайте від дитини абсолютної дисципліни, це призведе до зниження працездатності та засвоєння навчального матеріалу.

2. Зберігайте спокій у будь-якій ситуаціï.

3. Дозволяйте дитині в разі виникнення труднощів звертатися до Вас.

4. Давайте короткі, чіткі вказівки.

5. Перед виконанням завдання обговорюйте правила.

6. Спрямовуйте рухливість такої дитини на виконання корисних справ (роздати зошити, полити квіти, втерти дошку тощо).

7. Привчайте дитину послідовно виконувати певні дії, контролювати й оцінювати ïx.

8. Не скупіться на похвалу дитини.

9. Не допускайте зниження самооцінки (порівняння дитини зі слухняними, спокійними ровесниками).

10. Створюйте ситуації, у яких така дитина зможе себе проявити.

11. Створюйте умови для рухової «розрядки».

12. По можливості ігноруйте негативні вчинки, а позитивні заохочуйте.

13. Спробуйте домовлятись із дитиною.

14. Сприяйте викоріненню агресії.

15. Навчайте необхідним соціальним нормам та навичкам спілкування.

\section{Пам'ятка для батьків.}

1. Забудьте про фізичні покарання! Якщо $є$ необхідність удаватися до покарань, то доцільно використати спокійне сидіння в певному місці після негативного вчинку.

2. Говоріть спокійно.

3. Намагайтеся спільно вирішувати проблеми.

4. Частіше хваліть дитину. Поріг iï чутливості до негативних стимулів дуже низький, тому гіперактивні діти не сприймають доган i покарань, однак чутливі до заохочень.

5. Допомагайте дитині розпочати виконання завдання, адже це - найважчий етап.

6. Не давайте одночасно кілька вказівок. Завдання не повинно мати складну конструкцію або складатися з кількох ланок.

7. Не дозволяйте відкладати виконання 
завдання.

8. Не давайте дитині доручень, які не відповідають рівню іiї розвитку, віку та здібностям.

9. Складіть список обов'язків дитини й почепіть його на стіну, підпишіть угоду на окремі види робіт.

10. Визначте разом із дитиною, що можна робити і чого не можна.

11. Привчіть дитину дотримуватися чіткого розпорядку дня.

12. Надайте можливість дитині активно рухатися (тривалі прогулянки на свіжому повітрі, спортивні ігри, біг та ін.).

13. Оберігайте дитину від перевтоми, бо це призводить до зниження самоконтролю $\mathrm{i}$ тим самим провокує наростання гіперактивності.

14. Виховуйте навички керування гнівом і агресією.

15. Поясніть гіперактивній дитині iі проблеми і навчіть їх розв'язувати.

Переконані, щоб допомогти гіперактивній дитині, обов'язково іiї позитивно мотивувати. Така мотивація з'явиться за умови розуміння вчителя, зацікавлення батьків у тому, щоб допомогти своїй дитині. Тільки спільна робота рідних і педагогів дасть позитивний результат.

3 метою з'ясування гіперактивності дітей дорослим (батькам, учителям) можна запропонувати тест «Знайди відмінності».

Активна дитина:
1. Активна, непосидюча, віддає перевагу рухливим заняттям, та якщо ії зацікавити може охоче читати книгу, малювати, конструювати та ін.

2. Багато говорить, ставить багато запитань, але не потребує відповіді на них.

3. Рідко трапляються порушення сну.

4. Має різний вияв активності (неспокійна вдома, але спокійна серед незнайомих людей).

5. Рідко провокує конфлікти, хоча іноді може «постояти за себе».

Гіперактивна дитина:

1. Постійно рухається, навіть коли втомлена.

2. Багато говорить, задає велику кількість питань та не потребує відповіді на них.

3. Неспокійний сон.

4. У будь-яких умовах виявляє активність.

5.Часто провокує конфлікти (б’ється, кусається, штовхається та ін.).

Переконані, у наданні психологічної допомоги гіперактивним дітям ефективною буде арт-терапія, оскільки вона підвищує адаптаційні здатності дитини до повсякденного життя в школі, знижує втому, ліквідує негативні емоційні стани та їх прояви, пов'язані 3 навчанням, спирається на здоровий потенціал особистості, внутрішні механізми саморегуляції, розвиває почуття внутрішнього контролю, допомагає вибудовувати стосунки 3 дитиною на основі любові та взаємної прихильності. 
Рекомендуємо шкільним психологам у роботі 3 гіперактивними дітьми молодшого шкільного віку комплекс занять, спрямованих на зниження тривожності, страхів, підвищення зосередження, самооцінки та отримання насолоди від мистецтва.

Заняття тривалістю 30-40 хвилин із частотою зустрічей 2 рази на тиждень. Кожне із занять має власну мету, яка передовсім підпорядкована головній меті.

Структура занять:

Заняття 1. Тема. «Знайомство». Мета: створити атмосферу спільності, почуття комфортності, зняти емоційне напруження, розвивати уваги, довіру і взаєморозуміння, налаштовувати на подальшу роботу.

Вправи: «Привітання», «Мої взаємини 3 родиною», «Малювання символічного «Світу, в якому я живу», «Малювання почуттів», «Прощання».

Заняття 2. Тем. «Тривожність, страх». Мета: знизити рівень тривожності, емоційного напруження, гармонізувати стосунки між дитиною і дорослим.

Вправи: «Привітання», «Що таке страх?», «Чого я боюся?», «Намалюй свій страх», «Прощання».

Заняття 3. Тема. «Образ «Я». Мета: розвивати зосередженість, усвідомлення свого внутрішнього потенціалу, розкривати особливості характерологічних рис, формувати позитивний емоційний стан.

Вправи: «Привітання», «Що врятує Ро- бінзона?», «Намалюй себе», «Намалюй маску гарбуза», «Прощання».

Заняття 4. Тема. «Самооцінка». Мета: розвивати уявлення про себе, формувати адекватну самооцінку.

Вправи: «Привітання», «Сходинка», «Намалюй своє ставлення до однокласників», «Намалюй яким тебе бачать друзі», «Прощання».

Заняття 5. Тема. «Толерантність». Мета: знизити рівень тривожності, розвивати уміння долати психологічні бар'єри, розвивати увагу.

Вправи: «Привітання», «Намалюй друзів», «Створення рельєфної картини», «Знайди відмінності», «Прощання».

Заняття 6. Тема. «Поділися радістю». Мета: знизити рівень тривожності, розвивати здатність до емпатії, уміння долати бар'єри у спілкуванні, виражати почуття мовою мистецтва, психокорекція емоційного стану.

Вправи: «Привітання», «Ліплення 3 пластиліну», «Мистецтво оригамі», «Підставка для олівців», «Прощання».

Дорослим потрібно пам'ятати про те, що гіперактивна дитина неймовірно чутлива, гостро реагує на будь-які зауваження, заборони. Їй іноді здається, що іiі ніхто не любить, навіть найрідніші люди - батьки. Вважаємо досить ефективними і дієвими в роботі з такими дітьми «Правила 8 обіймів», які пропонує Олена Нікітіна. «Обіймайте дитину не менше 8 разів на день, аби вона відчувала Вашу лю- 
бов, те, що вона Вам потрібна, - пропонує авторка. - Для будь-якої дитини це важливо, особливо для гіперактивної. Тим більше, що обійми заспокоюють і знімають напруження».

Проведене дослідження дає підстави стверджувати про необхідність проведення психокорекційної роботи з дітьми, батьками, педагогами для подолання проблеми гіперактивності. Дорослим потрібно пам'ятати про те, що допомога гіперактивній дитині - дуже тривалий та складний процес.

Висновки. Отже, якщо змінити поведінку гіперактивної дитини швидко не вдається (це вимагає часу), усе одно потрібно продовжувати систематичний комплексний корекційно-розвивальний підхід, який зумовлює особливості роботи з такими дітьми. Дорослим не слід забувати про це, щоб не допустити помилок у навчанні та вихованні, які потім складно виправити, адже психіка маленького індивіда - модель його подальшого розвитку. Формування стосунків між гіперактивними дітьми та їхніми батьками, а також учителями - своєрідний складний трикутник, у центрі якого - особливості розвитку такого школяра.

На нашу думку, проблема допомоги дітям із синдромом гіперактивності потребує більш детального вивчення науковцями, переконані, це дасть можливість недопущення ізоляції, відрахування зі школи, примусу приймати заспокійливі препарати, що лише веде до загострення цього явища, а також гальмування процесу формування особистості такої дитини.

Ми вважаємо: корекційні заходи стосовно гіперактивних учнів повинні мати комплексний характер, тобто проводитися за участю ряду спеціалістів: психоневролога, психолога, педагогів, батьків. Медичний працівник, який веде спостереження за дитиною і ставить діагно3, насамперед проводить відповідне лікування. Другою, не менш важливою функцією $€$ пояснення батькам причини виникнення гіперактивності та розробка індивідуальної програми допомоги дитині.

Отже, проблема психологічних особливостей молодших школярів із синдромом гіперактивності не повністю розкрита й вимагає подальшого дослідження; ми зробили лише деякі важливі кроки до її вирішення.

Перспективу подальших досліджень психологічних особливостей гіперактивних молодших школярів убачаємо в розробці комплексної корекційно-розвивальної роботи 3 дітьми, батьками, учителями для подолання проблеми гіперактивності.

\section{Перелік використаних джерел:}

1. Александровский Ю. А. Пограничные психические расстройства / Ю. А. Александровский. - М. : Медицина, 2000. -496 с.

2. Макаренко C. Психолого-медико-педагогічна допомога гіперактивним дітям/ С. Макаренко // Психолог. Шкільний світ. - 2008. - № 47. - С. 5-19.

3. Панфилова М. А. Графическая методика «Кактус»/ М. А. Панфилова // Обруч. - 2000. - №5.- С. 3-6. 
4. Панфилова M. A. Такие разные кактусы / М. А. Панфилова // Школьный психолог. - 1998. - № 19. $-18 \mathrm{c}$.

5. Фесенко E. B. Синдром дефицита внимания и гиперактивности у детей / Е. В. Фесенко, Ю. А. Фесенко. СПб. : Наука и Техника, 2010. - 384 с.

6. Фролова Т.О. Допомога гіперактивним дітям / Т.О. Фролова // Психолог. Шкільний світ.-2012.- №1. - С.818.

7. Чутко Л. С. Синдром нарушения внимания с гиперактивностью у детей и подростков / Л. С. Чутко, А. Б. Пальчик, Ю. Д. Кропотов. - СПб. : СПбМАПО, 2004. $112 \mathrm{c}$.

8. Heller $K$. A. Psychotogische Probleme der Hochbegabungsforschung / K. A. Heller // Zeitschrift fur Entwicklungspsychologie und Padagogische Psychologic Band XVIII. - Heft 4, 335-361.

9. Kramer F. Hypermotilitatsneurose / F. Kramer, H. Pollnow // Monatschr. Psychol. - 1932. - Vol. 82. - P. 1524.

10. Palmer E. D. An early description of ADHD (Inattention Subtype): Dr. Alexander Crichton and the «Mental Restlessness» (1798) / E. D. Palmer, S. Finger // Child Psychology and Psychiatry Reviews. - 6. - P. 66-73.

\section{References (Transliteration):}

1. Aleksandrovskiy Yu. A. Pogranichnyie psihicheskie rasstroystva (2000) / Yu. A. Aleksandrovskiy. - M. : Meditsina. -496 p.

2. Makarenko S. Psihologo-mediko-pedagogIchna dopomoga gIperaktivnim dItyam (2008) / S. Makarenko // Psiholog. ShkIlniy svIt. - 47. - P. 5-19.

3. Panfilova M. A. Graficheskaya metodika «Kaktus» (2000) / M. A. Panfilova // Obruch. - 5.- P. 3-6.

4. Panfilova M. A. Takie raznyie kaktusyi (1998)/ M. A. Panfilova // Shkolnyiy psiholog. - 19. - 18 p.

5. Fesenko E. $V$. Sindrom defitsita vnimaniya i giperaktivnosti u detey (2010) / E. V. Fesenko, Yu. A. Fesenko. - SPb. : Nauka i Tehnika. - 384 p.
6. Frolova T. O. Dopomoga gIperaktivnim dItyam (2012) /

T.O. Frolova // Psiholog. ShkIlniy svIt.-1. - P.8-18.

7. Chutko L. S. Sindrom narusheniya vnimaniya s giperaktivnostyu u detey i podrostkov(2004) / L. S. Chutko, A. B. Palchik, Yu. D. Kropotov. - SPb. : SPbMAPO. - 112 p.

8. Heller K. A. Psychotogische Probleme der Hochbegabungsforschung / K. A. Heller // Zeitschrift fur Entwicklungspsychologie und Padagogische Psychologic Band XVIII. - Heft 4.- P. 335-361.

9. Kramer F. Hypermotilitatsneurose (1932) / F. Kramer, H. Pollnow // Monatschr. Psychol.- Vol. 82. - P. 15-24.

10. Palmer E. D. An early description of ADHD (Inattention Subtype): Dr. Alexander Crichton and the «Mental Restlessness» (1798) / E. D. Palmer, S. Finger // Child Psychology and Psychiatry Reviews. - 6. - P. 66-73.

\section{Atamanchuk Nina}

PhD in philological sciences, assistant Professor of the Department of General, Age and Applied Psychology of Poltava V. G. Korolenko National Pedagogical University, Poltava (Ukraine)

\section{PSYCHOLOGICAL CHARACTERISTICS OF JUNIOR SCHOOL CHILDREN WITH CHILDREN'S SYNDROME OF HYPERACTIVITY}

\section{ABSTRACT}

The article is connected with theoretical analysis and empirical research of psychological peculiarities of hyperactive junior pupils.

The characteristics of types of violations of children of primary school age with hyperactivity syndrome are presented. Pupils Students with a lack of active attention: hard to keep an eye on; do not listen when somebody talk to them; with a great desire to take up the tasks, but never end it distracting on external stimuli; expe- 
riencing difficulties in self-organization; not collected, forgetful, things are often lost; avoid tasks that require mental effort; It is difficult to concentrate attention when performing tasks. Pupils with motor breakdown: always spinning; expressing signs of anxiety (knocking with your fingers, or can not sit comfortably in one place); sleeping much less than peers; enjoy talking a lot; too ruffled; not calm; They can not quietly, quietly play or do anything in their free time. Pupils are impulsive: answer without question; not able to wait their turn, often interrupt the interlocutor; poor focus; free behavior is poorly managed; when performing tasks behave in different ways and show unequal result.

It was found that the more pupils with hyperactivity syndrome are characterized by motor deflection. A high percentage of explored children have violations concerning the lack of active attention and impulsivity.

The basic psychological features of hyperactive children are characterized; It has been established that for hyperactive pupils there are quite frequent manifestations of nervousness, aggression, impatience, abrupt mood change, sensitivity to criticism or ignoring the comments of adults, etc.

The psychological features of children of the junior school age with hyperactivity syndrome are revealed, namely: inconsistent in the tasks performed; often diverted to third-party stimuli; prone to abrupt mood change; inattentive; unable to bring the matter to an end; find difficul- ties in self-organization; distraction; things are often lost; forgetful; impatient; Can not sit on the spot; shout; talkative; Excessive motor activity on breaks and lessons; aggressive; answer without listening to the question; do not wait for their turn; sensitive to criticism; interrupt the interlocutor; ignore adult comments; not able to control and regulate their actions; behavior is poorly managed, impulsive.

It is concluded that hyperactive children did not have a delay in intellectual development, but problems in education arose mainly due to insensitivity, inability to focus attention and bad memory. Having enough potential to learn the curriculum, these children are unwanted at school, classmates do not accept them. Hyperactive children often show cruelty to their peers, they are the culprits of conflicts, which leads to tense situations.

We see the prospect of further research on the problem of psychological peculiarities of hyperactive junior students in the development of complex correction and developmental methods for working with such children.

Key words: hyperactivity, lack of active attention, impulsivity, motor breakdown, external manifestations of hyperactivity. 


\section{Атаманчук Нина Михайловна}

Кандидат психологических наук, доиент кафедры общей, возрастной и практической психологии Полтавского национального педагогического университета имени В. Г. Короленко, г. Полтава (Украина)

\section{ПСИХОЛОГИЧЕСКИЕ ОСОБЕННОСТИ ДЕТЕЙ МЛАДШЕГО ШКОЛЬНОГО ВОЗРАСТА С СИНДРОМОМ ГИПЕРАКТИВНОСТИ}

Аннотация. Статья связана с теоретическим анализом и эмпирическим исследованием психологических особенностей гиперактивных младших школьников.

Поданы характеристики типов нарушений детей младшего школьного возраста с синдромом гиперактивности. Ученики с дефицитом активного внимания: трудно удерживают внимание; не слушают, когда к ним обращаются; с большим желанием берутся за выполнение заданий, но так и не заканчивают его, отвлекаясь на посторонние раздражители; испытывают трудности в самоорганизации; не собранные, забывчивые, часто теряют вещи; избегают выполнений заданий, которые требуют умственных усилий; трудно концентрируют внимание при выполнении заданий. Ученики с двигательной расторможенностью: постоянно вертятся; обнаруживают признаки обеспокоенности (не могут спокойно сидеть на одном месте); спят намного меньше, чем ровесники; любят много говорить; слишком подвижные; не спокойные; не могут тихо, спокойно заниматься чем-либо в свободное время. Ученики импульсивные: отвечают, не до- слушав вопрос; не способны ожидать своей очереди, часто перерывают собеседника; плохо сосредоточивают внимание; безвольные; поведение слабо управляется; при выполнении заданий ведут себя по-разному и показывают неодинаковый результат.

Обнаружено, что больше всего учеников с синдромом гиперактивности характеризуются двигательной расторможенностью. Большой процент среди исследуемых детей имеют нарушения, что касаются дефицита активного внимания и проявлений импульсивности.

Установлено, что для гиперактивных школьников являются достаточно частыми проявления нервозности, агрессии, нетерпеливости, резкого изменения настроения, чувствительность к критике или игнорирование замечаний взрослых и др. Обнаружены психологические особенности детей младшего школьного возраста с синдромом гиперактивности, а именно: непоследовательные в выполненных заданий; часто отвлекаются на посторонние раздражители; склонны к резкому изменению настроения; невнимательные; не способные доводить начатое дело до конца; обнаруживают трудности в самоорганизации; не собранные; часто теряют вещи; забывчивые; нетерпеливые; не могут усидеть на месте; выкрикивают; разговорчивые; проявляют избыточную двигательную активность на перерывах и уроках; агрессивные; отвечают не дослушав вопрос; не ожидают своей очереди; 
чувствительны к критике; перерывают собеседника; игнорируют замечание взрослых; не способны контролировать и регулировать свои действия; поведение слабо управляется; импульсивные.

Сделан вывод, что гиперактивные дети не имели задержки интеллектуального развития, но проблемы в учебе возникали преимущественно через непоседливость, неумение концентрировать внимание и плохую память. Имея достаточный потенциал для усвоения учебной программы, эти деть является нежелательными в школе, одноклассники их не воспринимают. Гиперактивные дети достаточно часто проявляют жестокость к своим ровесникам, они являются виновниками конфликтов, что вызывает напряженные ситуации.

Рассматриваем перспективу последующих исследований проблемы психологических особенностей гиперактивных младших школьников в разработке комплексных корекционно-развивающих методов работы с такими детьми.

Ключевые слова: гиперактивность, дефицит активного внимания, импульсивность, двигательная расторможенность, внешние проявления гиперактивности. 